\title{
KESETARAAN GENDER DALAM BINGKAI HUKUM DAN KEWARGANEGARAAN DI INDONESIA
}

\author{
Yesi Eka Pratiwi \\ Pendidikan Pancasila dan Kewarganegaraan \\ Program Paskasarjana Universitas Negeri Yogyakarta \\ yesiekapratiwi2@gmail.com
}

\begin{abstract}
Abstrak
Kewarganegaraan merupakan status yang diberikan pada seseorang untuk menjadi anggota penuh dalam sebuah masyarakat. Semua yang memiliki status tersebut memiliki hak dan kewajiban yang sama dengan status yang dianugerahkan oleh suatu negara. Hakikat kewarganegaraan itu sendiri ialah ikatan hukum antara negara dan seseorang, ikatan itu menjadi sebuah kontrak politis antara negara yang mendapat status sebagai negara yang berdaulat dan diakui karena memiliki tata negara. Kewarganegaraan dapat dikatakan sebagai suatu hal-hal yang berhubungan dengan penduduk dalam suatu bangsa, kewarganegaraan di pandang sebagai hak untuk berpartisipasi secara utuh dalam berbagai pola struktural sosial, politik dan budaya. Berkaitan dengan hak- hak kewarganegaraan pada saat itu suatu faham feminisme yang muncul ketika wanita menuntut untuk mendapatkan kesetaraan Hak yang sama dengan pria. Pengakuan tentang ketidak seimbangan gender, dengan peran wanita yang berada di bawah pria. Timbulnya faham feminisme yang menuntut kesetaraan gender terhadap hak-hak kewarganegaraan yang diperolehnya sebagai warga negara,di mana perempuan sebagai agen (perubahan) dan warga negara juga ingin diakui oleh lembaga politik, ekonomi, maupun sosial yang selama ini di dominasi laki-laki. Penulisan ini bertujuan untuk memaparkan tentang kewarganegaraan dan kesetaraan gender. Penulisan ini menggunakan metode kajian pustaka.
\end{abstract}

Kata Kunci: kesetaraan, kewarganegaraan, gender 


\section{A. Pendahuluan}

Era reformasi menuntut perubahan paradigma dalam penyelenggaraan negara yang lebih demokratis dan berdasarkan prinsip negara hukum yang memperkuat perlindungan hak asasi manusia dan persamaan kesederajatan didepan hukum bagi setiap warga negara. Wujud perubahan tersebut secara konstitusional terihat dari adanya amandemen UUD 1945 yang bertujuan untuk menyempurnakan aturan dasar mengenai tatanan negara dalam mencapai tujuan nasional yang tertuang dalam pembukaan UUD 1945, menyempurnakan aturan dasar mengenai jaminan dan pelaksanaan kedaulatan rakyat, menyempurnakan Aturan dasar mengenai jaminan dan perlindunga hak asasi manusia, menyempurnakan aturan dasar penyelenggaraan negara secara demokratis dan modern, menyempurnakan aturan dasar mengenai jaminan konstitusional dan kewajiban negara mewujudkan kesejahteraan sosial, melengkapi aturan dasar yang sangat penting dalam penyelenggaraan negara, menyempurnakan aturan dasar mengenai kehidupan dan beregara dan berbangsa. Gagasan tersebut menyentuh pola persoalan kewarganegaraan yang harus ditata kembali sesuai dengan tuntutan demokratisasi dan kebutuhan reformasi lainnya agar masalah hak-hak dan perlindungan warga negara dapat diposisikan secara tepat didalam rangka perlindungan HAM tanpa mengganggu kedaulatan Negara Kesatuan Republik Indonesia.

Gagasan tersebut kemudian diwujudkan dengan adanya reformasi peraturan perundang undangan tentang kewarganegaraan yang secara resmi yang dituangkan dalam UU No.12 tahun 2006 tentang kewarganegaraan. UU tersebut menggantikan UU No.62 Tahun1958 tentang kewarganegaraan.

Kewarganegaran pada saat yang sama dapat dilihat dari hasil proses tawar menawar di mana anggota komunitas pilitik mengharapkan dan menuntut hak tertentu kepada anggota warga negara. Meskipun dalam pengertian tentang warga negara dapat dilihat sebagai ukuran timbal balik di mana adanya tindakan yang seimbang antara hubungan hak dan kewajiban.

Adanya pernyataan bahwa kewarganegaraan itu sederhananya adalah ketika individu menjadi seorang pemegang paspor. Menurut Torpey dalam Kivisto \& Faist (2007: 50) paspor adalah salah satu tanda nyata kebangsaan. Di dalam bukunya Kivisto \& Faist yang berjudul Citizenship menjelaskan bahwa pada era kewarganegaraan modern antara kebangsaan dan kewarganegaraan itu sudah terikat atau terkait dengan erat, namun untuk sebuah kewarganegaraanya perlu dibedakan secara analitis. Kebangsaan itu berarti keanggotaan penuh dalam sebuah negara dan terikat dengan sistem hukum negara tersebut, juga dengan itu pula individu tunduk pada kekuasaan negara. 
Tilli \& Beland dalam Kivisto \& Faist (2007: 51) menjelaskan adanya fungsi kebangsaan antar negara (internasional) adalah untuk mendefinisikan orang-orang di dalam wilayah yang digariskan dan untuk melindungi warga negara terhadap dunia luar yang terkadang bermusuhan, kemudian ada pula fungsi domestik yakni untuk mendefinisikan hak dan kewajiban tiap individu. Adanya prinsip domaine reservee (kompetensi ekslusif), yakni memberikan setiap negara untuk memutuskan batas dan penentuan nasibnya sendiri dan kriteria yang dibutuhkan untuk mengakses warga negaranya. Salah satu syarat umum untuk keanggotaan itu ialah warga negara memiliki semacam hubungan erat dengan negaranya.

Adrian Oldfield mengonsepsikan dua pendekatan, yakni kewarganegaraan sebagai status dan kewarganegaraan sebagai praktik. Pendekatan pertama memprioritaskan hak warga negara sebagai individu, sedangkan pendekatan kedua pada kepentingan masyarakat yang lebih luas. Tetapi gagasan kewarganegaraan kerap dikritik terlalu individual dan anti sosial karena doktrinnya tentang hak individu. Kewarganegaraan, dan komunitarianisme sebagai turunannya, berasal dari doktrin individualisme posesif dan kebebasan yang negatif. Mereka adalah akomodasi intelektual dengan kebutuhan untuk pengaturan sosial, tetapi pada intinya mereka tetap anti-sosial, baik dalam makna sosiologis maupun popular (Byrne, 2005:2).

Itulah mengapa upaya melihat kewarganegaraan sebagai sebuah proses dan bukan semata-mata hasil yang penting untuk dilakukan, mengombinasikan elemen dari dua tradisi sejarah kewarganegaraan, yakni tradisi republikan partisipatoris dan tradisi hak-hak sosialliberal, Ini merupakan upaya untuk melihat bahwa warga negara bukan sekadar pemegang hakhak pasif, tapi juga aktif terlibat dengan lembaga politik dan kesejahteraan, baik sebagai individu maupun kelompok. Dalam konteks perspektif feminis, menurut Lister (2003: 4), pendekatan kewarganegaraan juga ingin dilihat apakah memberi kemungkinan posisi perempuan sebagai agen (perubahan) dibanding sebagai korban dari diskriminasi dan opresi dari lembaga politik, ekonomi, maupun sosial yang didominasi laki-laki.

Kesetaraan antara laki-laki dan perempuan atau lebih dikenal dengan istilah kesetaraan gender telah menjadi pembicaraan yang hangat akhirakhir ini. Melalui perjalanan panjang untuk meyakinkan dunia bahwa perempuan telah mengalami diskriminasi hanya karena perbedaan jenis kelamin dan perbedaan secara sosial, akhirnya pada tahun 1979, Perserikatan BangsaBangsa (PBB) menyetujui konferensi mengenai penghapusan segala bentuk diskriminasi terhadap perempuan.

Konferensi ini sebenarnya telah diratifikasi oleh Indonesia pada tahun 1984 menjadi UU No. 7/1984, tetapi jarang disosialisasikan dengan baik oleh negara. Konferensi maupun Undang-Undang tersebut pada kenyataannya tidak juga sanggup menghapus diskriminasi yang 
dialami oleh perempuan. Di seluruh dunia masih ada perempuan yang mengalami segala bentuk kekerasan (kekerasan fisik, mental, sosial dan ekonomi) baik di rumah, di tempat kerja maupun di masyarakat.

Di Indonesia bukanlah hal yang baru bahwa perempuan sering mengalami proses ketidakadilan gender melalui marginalisasi, subornasi, stereotipe serta menjadi korban kekerasan. Hal ini bersangkutan dengan tarik menarik antara peran domestik dan peran publik perempuan. Proses marginalisasi, yang mengakibatkan kemiskinan banyak sekali terjadi dalam masyarakat dan negara yang menimpa kaum laki-laki dan perempuan, misalnya penggusuran, bencana alam, atau proses ekploitasi.

Pandangan gender juga dapat menimbulkan subornasi, anggapan bahwa perempuan irrasional atau emosional sehingga perempuan tidak bisa tampil menjadi pemimpin, berakibat munculnya sikap yang menempatkan perempuan pada posisi yang tidak penting ataupun dinomor duakan, serta secara umum steriotipe terhadap perempuan adalah pelabelan atau penandaan terhadap suatu kelompok tertentu yang mana pandangan tersebut bersumber dari gender.

Adanya pandangan terhadap kesetaraan gender dalam perspektif kewarganegaraan, seringkali menimbulkan berbagai isu kewarganegaraan yang muncul kepermukaan sehingga berdampak pada kehidupan sosial dan mucul lah faham feminisme.Feminisme adalah sebuah paham yang muncul ketika wanita menuntut untuk mendapatkan kesetaraan Hak yang sma dengan pria. Pengakuan tentang ketidak seimbangan gender, dengan peran wanita yang berada di bawah pria. Pada awal abad ke 18 dapat dikatakan sebagai awal dalam sejarah feminisme, walaupun sudah ada wanita yang melakukan debat untuk mendapatkan posisi yang di akui dalam masyarakat, feminisme belum terlalu banyak berkembang pada saat itu. Pada saat itu yang bermunculan adalah para wanita yang menulis karya yang menunjukan tuntutan mereka untuk mendapatkan persamaan hak, khususnya di dalam bidang pendidikan.

\begin{tabular}{|c|l|l|}
\hline ASPEK PEMBEDA & \multicolumn{1}{|c|}{ LAKI-LAKI } & \multicolumn{1}{c|}{ PEREMPUAN } \\
\hline Peran Sosial & $\begin{array}{l}\text { Organisasi politik } \\
\text { Pencari nafkah utama } \\
\text { Pelindung keluarga } \\
\text { Pengambil } \\
\text { keputusan/kebijakan }\end{array}$ & $\begin{array}{l}\text { Komunitas setempat } \\
\text { (arisan, PKK, Keluarga, } \\
\text { Pengajian) Pencari nafkah } \\
\text { tambahan/ pengganti } \\
\text { Perawat, pendidik anak }\end{array}$ \\
\hline Sifat Kegiatan & Publik & Domestik \\
\hline
\end{tabular}




\begin{tabular}{|l|l|l|}
\hline & Produktif & Bersifat produktif T \\
& Berupa lebih besar & Tidak berupah/ rendah \\
Membutuhkan & Dianggap alamiah \\
keterampilan terlatih/ & Manajemen sederhana \\
terdidik Membutuhkan & Penggunaan teknologi \\
manajemen modern & terbatas Penerimaan \\
Melibatkan teknologi & kekuasaan Sektor informal \\
kelibatkan aspek & Sektor formal & \\
\hline Pekerjaan & $\begin{array}{l}\text { Sopir } \\
\text { Pengusaha Satpam } \\
\text { Mandor }\end{array}$ & Sekretaris Pedagang kecil \\
Pramugari
\end{tabular}

perbedaan-perbedaan gender yaitu pada peran-peran yang berbeda yang dimainkan lakilaki dan perempuan dalam berbagai institusional. Peran-peran perempuan di institusi keluarga misalnya sebagai seorang ibu bagi anak dan istri bagi suaminya. Motif utama dari perspektif ini adalah pembagian kerja dilihat dari jenis kelamin (laki-laki dan perempuan) di dalam institusi keluarga. Menjadi sebuah dilematis ketika dalam pemilihan karir antaramenyesuaikan passion(kerja) dengan menjadi Ibu Rumah Tangga atau pula keduanya (berkarir dan menjadi ibu Rumah Tangga). Seharusnya perempuan dan lak-laki tidak ada beda dalam perlakuan (Mufidah, 2006: 4).

Ruth Lister (2003: 7) merangkum berbagai gagasan para sarjana feminis mengenai peran warga negara, terutama hak dan kewajiban warga negara dalam kaitannya dengan partisipasi politik. Seperti juga di Indonesia, perempuan dianggap sebagai warga negara, tanpa pembedaan yang tersurat dalam hak dan kewajiban dengan warga negara laki-laki. Akan tetapi yang penting adalah untuk membedakan antara peran aktif dan peran pasif sebagai warga negara. Lister menyitir Mary Dietz yang menyatakan bahwa partisipasi politik adalah terminologi yang menjadi lawan peran pasif warga negara sebagai 'pemilik hak'.

Partisipasi politik berarti secara aktif melakukan sesuatu dalam kaitan dengan kewajiban sebagai warga negara, yakni mempengaruhi kebijakan publik. Lister mengutip Diemut Bubeck yang menyarankan bahwa kerja domestik dan pengasuhan seharusnya juga menjadi kewajiban 
warga negara, sehingga beban kerja ini tidak hanya diletakkan pada pundak perempuan dan menghalangi perempuan memiliki ruang kemungkinan yang lebih luas untuk bergerak, tanpa dihalangi kewajiban kultural sebagai pengurus ranah domestik yang dibebankan kepadanya.

\section{B. Pembahasan}

Gender merupakan salah satu isu, yang hangat dan menarik diperbincangkan. Istilah gender mengandung arti seperangkat sikap, peran, tanggung jawab, fungsi, hak dan perilaku yang melekat pada diri laki-laki dan perempuan akibat bentukan budaya atau lingkungan masyarakat tempat dimana manusia itu tumbuh dan dibesarkan. Setiap masyarakat selalu ada pembagian kerja antara laki-laki dan perempuan, sehingga dikenal dengan peran gender yang berbeda antara laki-laki dan perempuan.

Perbedaan gender sesungguhnya merupakan hal yang biasa atau suatu kewajaran sepanjang tidak menimbulkan ketidakadilan gender. Ketidakadilan gender dapat menyebabkan pembagian peran dan tanggung jawab yang berlebih pada salah satu pihak, yakni perempuan atau laki-laki. Perbedaan gender ternyata telah menyebabkan munculnya berbagai ketidakadilan gender yang terjadi dalam keluarga dan masyarakat. Ketidakadilan gender tentu perlu diperjuangkan menjadi keadilan atau kesetaraan gender (Zakia, 2011: 39).

Gender adalah perbedaan peran, fungsi, persifatan, kedudukan, tanggung jawab dan hak perilaku,baik perempuan, maupun laki-laki yang dibentuk, dibuat, dan disosialisasikan oleh norma, adat kebiasaan, dan kepercayaan masyarakat setempat. Dalam kaitan ini, konsep gender berhubungan denganperan dan tugas yang pantas/tidak pantas, baik untuk laki-laki, maupun perempuan. Adapun relasi gender adalah hubungan antara laki-laki dan perempuan berkaitan dengan pembagian peran yang dijalankan masing-masing pada berbagai tipe dan struktur keluarga (keluarga miskin/kaya, keluarga desa/kota, keluarga lengkap/tunggal, keluarga punya anak/tidak punya anak, keluarga pada berbagai tahapan life cycle). Bahkan, relasi gender ini juga diperluas secara bertahap berdasarkan luasan ekologi, mulai dari mikro, meso, ekso, dan makro (keluarga inti, keluarga besar, masyarakat regional, masyarakat nasional, bangsa dan negara dan masyarakat internasional) (Puspitawati, 2010: 18).

Terdapat dua kelompok atau golongan yang mendefinisikan gender secara berbeda. Kelompok yang pertama adalah sekelompok feminis yang mengatakan bahwa perbedaan jenis kelamin tidak menyebabkan perbedaan peran dan perilaku gender dalam tataran sosial. Kelompok kedua menganggap bahwa perbedaan jenis kelamin akan menyebabkan perbedaan perlakuan atau peran berdasarkan gender. Misalnya, ada perlakuan khusus pada pekerja wanita 
karena kondisi biologisnya, seperti cuti hamil, cuti haid, pemberian jam kerja malam, dan sebagainya.

Gender diartikan sebagai konstruksi sosio kultural yang membedakan karakteristik maskulin dan feminin. Gender berbeda dengan seks atau jenis kelamin laki-laki dan perempuan yang bersifat biologis. Walaupun jenis kelamin laki-laki sering berkaitan erat dengan gender maskulin dan jenis kelamin perempuan dengan gender feminin, namun kaitan antara jenis kelamin dengan gender bukan merupakan korelasi absolut (Puspitawati, 2010: 19).

Mewujudkan Kesetaraan dan Keadilan gender (KKG) bukanlah merupakan suatu yang mudah, tetapi memerlukan perjuangan yang ekstra keras karena hal ini berkaitan erat dengan perubahan nilai budaya atau konstruksi sosial budaya yang telah berurat akar di masyarakat. Namun demikian, karena semua nilai budaya yang ada di masyarakat adalah bentukan manusia, maka pada prinsipnya hal ini bisa diubah tetapi memerlukan proses yang panjang. Melalui upaya yang serius dan berkesinambungan maka secara lambat laun ideologi gender yang bersifat merugikan salah satu jenis kelamin akan dapat dikikis sehingga pada gilirannya kesetaraan dan keadilan gender dimasyarakat Indonesia pada umumnya dan di Bali khususnya akan dapat terwujud. Terwujudnya kesetaraan dan keadilan gender berarti masyarakat kita telah mampu memenuhi salah satu kesepakatan Millenium Development Goals (MDGs) yang telah menjadi komitmen Internasional (Arjani, 2008: 116). Pengertian secara harfiah kata setara disebut juga dengan seimbang, tidak berat sebelah dan tidak membeda-bedakan. Kalau dikaitkan dengan gender berarti tidak melihat dari jenis kelamin yang bersifat biologis akan tetapi dilihat dari kemampuan dan kualitas dari seseorang (Suryani, 2010: 8).

Pernyataan tersebut secara implisit mengemukakan bahwa ada ketidaksamaan hak antara laki-laki dan perempuan didunia ini, sehingga perlu dibuat dalam sebuah pernyataan agar negara, maupun masyarakat, mengindahkan persamaan hak tersebut sebagai sebuah hak asasi manusia. Gerakan feminis di negara Amerika Serikat sudah dimulai jauh sebelum masa itu, misalnya seorang Feminis Amerika yang bernama Elizabeth Cady Stanton (1815-1902) yang memprakarsai konvensi hak-hak perempuan tahun 1848 di Seneca Falls dan memperjuangkan hak suara kaum perempuan di negara itu (Hadiz, 1998), namun baru seratus tahun kemudian PBB secara resmi menyampaikan deklarasi tentang hak asasi manusia termasuk hak perempuan dan laki-laki. Ini juga sebuah pertanda bahwa demikian tidak mudah untuk mencapai kesetaraan dan keadilan gender, baik di negara maju maupun di negara berkembang seperti Indonesia (Marheni, 2012:3).

Melalui penelitian yang dilakukan oleh Prasetio, dkk (2014: 7) menjelaskan bahwa sesuai dengan Peraturan Pemerintah Nomor 100 Tahun 2000 yang telah diubah dengan 
Peraturan Pemerintah Nomor 13 Tahun 2003 dalam Jabatan Struktural tentang Pegangkatan PNS dalam Jabatan Struktural dan Peraturan Daerah (Perda) Kota Semarang Nomor 3 Tahun 2010 tentang Persyaratan Menduduki Jabatan Struktural. Tidak ada diskriminasi atau perbedaan perlakuan pegawai negeri sipil perempuan maupun laki-laki dan memiliki kesetaraan dan keadilan yang sama dalam pengisian jabatan struktural kepala dinas. Fakta praktek yang ada, karena adanya kurangn Sumber Daya Manusia kaum perempuan untuk bidang tertentu. Sejauh ini belum ada program pemerintah Kota Semarang untuk memperbaiki kualitas SDM untuk kaum perempuan yang sesuai ahli di bidang teknis. Faktor dari, jabatan struktural pemerintah berbentuk piramida sehingga tidak semua bisa naik ke jenjang tertinggi. Namun demikian adanya peran faktor tradisi atau budaya, dimana PNS perempuan didalam menjabat kepala dinas ditempatkan pada jenis dinas yang pekerjaan yang memiliki tanggung jawab yang kecil.

Gagasan mengenai kesetaran peran yang didasarkan pada jenis kelamin sering kali dinilai masih memiliki sejarah yang bisa dikatakan pendek. Setidaknya kesimpulan itu tergambar dari adanya realita bahwa sampai dengan akhir abad XIX perempuan diperlakukan sebagai jenis kelamin yang lebih inferior jika dibandingkan dengan jenis kelamin laki-laki yang disetereotipekan lebih superior. Inferioritas jenis kelamin perempuan tersebut terutama terletak pada perlakuan mengecualikan perempuan untuk ikut serta dalam peran publik. Seperti Politik, Pendidikan, dan profesi tertentu. Indonesia memandang sejak kelahirannya, Undang-Undang Dasar 1945 tidak pernah melakukan diskriminasi terhadap perempuan. Hal ini karena para perancang konstitusi Indonesia sejak awal memiliki kesadaran untuk tidak melanjutkan diskriminasi perempuan prakemerdekaan dan membuka lembaran baru relasi perempuan \& laki-laki pasca kemerdekaan melalui formalisasi dalam Undang-Undang Dasar 1945. Setidaknya hal tersebut muncul dari semangat yang dikembangkan oleh Soekarno dengan pernyataan retorikanya mengenai “Gerakan Politik dan Emansipasi Perempuan” (Thohari, 2012: 2).

Kesetaraan gender di bidang politik merupakan bagian dari pencapaian MDGS 2015. Salah satu institusi yang memiliki peran krusial dalam upaya menuju kesetaraan gender adalah partai politik. Posisi strategis partai dapat dilakukan melalui berbagai kebijakan internal. Kebijakan tersebut berkaitan dengan strategi pembinaan yang dilakukan terhadap kader perempuan anggota partai politik, proses rekrutmen yang lebih adil ataupun kebijakankebijakan lain yang perlu diambil. Hal ini penting guna meningkatkan peran serta perempuan dalam politik, terutama dalam meningkatkan keterwakilan perempuan di lembaga legislatif, baik secara kuantitas maupun kualitas (Alrafni, 2013: 145). 
Ch, Mufidah (2006: 4) melalui penelitiannya memaparkan bahwa Perbedaan gender (gender differences) antara manusia laki-laki dan perempuan terjadi melalui proses yang panjang. Pembentukan gender ditentukan oleh sejumlah faktor yang ikut membentuk, kemudian disosialisasikan, diperkuat, bahkan di konstruk melalui sosial atau kultural, dilanggengkan oleh interpretasi agama dan mitos-mitos, seolah-olah telah menjadi keyakinan. Proses selanjutnya perbedaan gender dianggap suatu ketentuan Tuhan yang tidak dapat diubah sehingga perbedaan tersebut dianggap kodrati. Untuk memahami perbedaan antara seks dan gender dapat dilihat pada tabel berikut ini:

\begin{tabular}{|c|c|c|c|}
\hline IDENTIFIKASI & LAKI-LAKI & PEREMPUAN & SIFAT \\
\hline Ciri Biologis & $\begin{array}{l}\text { Penis } \\
\text { Jakun } \\
\text { sperma }\end{array}$ & $\begin{array}{l}\text { Vagina } \\
\text { Payudara (ASI) } \\
\text { Ovum } \\
\text { Rahim } \\
\text { Haid } \\
\text { Hamil/melahirka } \\
\text { n Menyusui }\end{array}$ & $\begin{array}{l}\text { Tetap, tidak dapat } \\
\text { dipertukarkan. Kodrati } \\
\text { Pemberian Tuhan. }\end{array}$ \\
\hline Sifat/Karakter & $\begin{array}{l}\text { Rasional } \\
\text { Kuat } \\
\text { Cerdas } \\
\text { Pemberani } \\
\text { Superior } \\
\text { Maskulin }\end{array}$ & $\begin{array}{l}\text { Emosional } \\
\text { Lemah } \\
\text { Bodoh } \\
\text { Penakut } \\
\text { Inferior } \\
\text { Feminin }\end{array}$ & $\begin{array}{l}\text { Ditentukan oleh } \\
\text { masyarakat. } \\
\text { Disosialisasikan. } \\
\text { Dimiliki oleh laki-laki } \\
\text { dan perempuan. Dapat } \\
\text { berubah sesuai } \\
\text { kebutuhan }\end{array}$ \\
\hline Peran & $\begin{array}{l}\text { Kepala } \\
\text { keluarga } \\
\text { Pencari } \\
\text { nafkah } \\
\text { Pemimpin } \\
\text { Direktur } \\
\text { Kepala } \\
\text { kantor } \\
\text { Pilot }\end{array}$ & $\begin{array}{l}\text { Ibu rumah } \\
\text { tangga } \\
\text { Manajemen } \\
\text { rumah tangga } \\
\text { Dipimpin } \\
\text { Sekretaris } \\
\text { Pramugari } \\
\text { Perawat } \\
\text { Pembantu }\end{array}$ & $\begin{array}{l}\text { Konstruk masyarakat } \\
\text { Dapat berubah sesuai } \\
\text { kebutuhan }\end{array}$ \\
\hline
\end{tabular}




\begin{tabular}{|l|l|l|l|}
\hline & Dokter & rumah tangga & \\
Sopir & Buruh & \\
Mandor & & \\
\hline
\end{tabular}

Pujiastuti (2012: 82) melalui penelitiannya memaparkan bahwa, pergeseran cara pandang atas peran gender terus berkembang secara dinamis di masyarakat, termasuk di birokrasi, pro-kontra terhadap kesetaraan gender akan terus ada sepanjang jaman. Ketimpangan antara perempuan dan laki-laki terutama di ranah publik juga akan terus menjadi perdebatan karena meskipun ada pengakuan kesetaraan hak, seringkali tidak diikuti oleh adanya gerakan untuk memberikan kesempatan yang sama. Itulah sebabnya meskipun jumlah perempuan di Birokrasi terus bertambah jumlahnya, masih tidak mudah bagi mereka untuk menembus sebagi elit.

Dari pengertian di atas penulis dapat menyimpulkan bahwa kesetaraan gender adalah laki-laki dan perempuan dapat memperoleh akses, control, partisipasi, manfaat yang sama dalam menwujudkan pembangunan. Penilaian dan penghargaan yang sama diberikan oleh masyarakat terhadapa persamaan dan perbedaan perempuan dan laki-laki dalam berbagai peran yang mereka jalankan.

Gagasan kewarganegaraan muncul dari Barat. Para teoritisi kontemporer menggambarkan gagasan ini sebagai “aspek kunci dari pemikiran politik Barat sejak pembentukan budaya politik Yunani klasik" dan "satu dari pusat pengorganisiran fitur dari wacana politik Barat” (Lister, 2003). Sosiolog Inggris, T.H Marshall, mendefinisikan kewarganegaraan sebagai “status yang diberikan pada orang yang menjadi anggota penuh sebuah masyarakat. Semua yang memiliki status tersebut memiliki hak dan tugas yang sama dengan status yang dianugerahkan.”Dalam konteks keanggotan ini, menurut Hall and Held, “politik kewarganegaraan dimulai.” Ini bukan hanya melibatkan tatanan hukum yang mengatur hubungan antara individu dengan negara, tapi juga tatanan hubungan sosial antara individu dengan negara dan antar individu warga negara. Dengan demikian relasi ini bisa dinegosiasikan (Stasiulis dan Bakan, 1997).

Sementara Adrian Oldfield (1990) mengonsepsikan dua pendekatan, yakni kewarganegaraan sebagai status dan kewarganegaraan sebagai praktik. Pendekatan pertama memprioritaskan hak warga negara sebagai individu, sedangkan pendekatan kedua pada kepentingan masyarakat yang lebih luas. Tetapi gagasan kewarganegaraan kerap dikritik terlalu individual dan anti sosial karena doktrinnya tentang hak individu. Kewarganegaraan, dan komunitarianisme sebagai turunannya, berasal dari doktrin individualisme posesif dan 
kebebasan yang negatif. Mereka adalah akomodasi intelektual dengan kebutuhan untuk pengaturan sosial, tetapi pada intinya mereka tetap anti-sosial, baik dalam makna sosiologis maupun popular (Byrne, 2005).

Itulah mengapa upaya melihat kewarganegaraan sebagai sebuah proses dan bukan semata-mata hasil yang penting untuk dilakukan, mengombinasikan elemen dari dua tradisi sejarah kewarganegaraan, yakni tradisi republikan partisipatoris dan tradisi hak-hak sosialliberal, Ini merupakan upaya untuk melihat bahwa warga negara bukan sekadar pemegang hakhak pasif, tapi juga aktif terlibat dengan lembaga politik dan kesejahteraan, baik sebagai individu maupun kelompok. Dalam konteks perspektif feminis, menurut Lister (2003), pendekatan kewarganegaraan juga ingin dilihat apakah memberi kemungkinan posisi perempuan sebagai agen (perubahan) dibanding semata-mata sebagai korban dari diskriminasi dan opresi dari lembaga politik, ekonomi, maupun sosial yang didominasi laki-laki.

Ada dua jenis pendekatan kewarganegaraan, yakni pendekatan hak dan pendekatan kewajiban. Pendekatan hak berasal dari tradisi politik liberal yang muncul pada abad ke-17 sebagai upaya negara berdaulat dalam menjamin kebebasan warganya. Negara memberikan hak sipil dan hak politik bagi warganya.Sementara pendekatan kewarganegaraan sebagai kewajiban berakar pada tradisi republikan yang lebih tua dari era Yunani klasik dimana partisipasi politik merupakan kewajiban warga negara dan ekspresi penuh warga negara sebagai mahluk politik yang mewakili esensi kewarganegaraan sebagaimana diartikulasikan oleh Aristoteles (Lister, 2003).

Meskipun menurut Roche (1992), kewajiban kewarganegaraan saat ini ditafsirkan lebih luas sebagai “wacana tugas.” Wacana ini merefleksikan “pendekatan ketiga”, yakni komunitarian yang memiliki pertalian kuat dengan tradisi republik sipil, dengan asumsi dan kepedulian serupa yakni penolakan pada kewarganegaraan yang berbasis hak individu. Pada pendekatan hak, menekankan pada hak sipil, politik, dan sosial. Menurut Marshall, hak sipil merupakan hak yang diperlukan bagi kebebasan individu, diantaranya hak kebebasan bicara, berpikir, dan berkeyakinan; hak memiliki kekayaan, dan hak atas keadilan. Sementara hak politik adalah hak berpartisipasi dalam aktivitas politik, termasuk hak dipilih maupun memilih dalam pemilu. Sedangkan hak sosial adalah hak untuk memperoleh kesejahteraan, baik sosial maupun ekonomi.

Khusus tentang hak sosial, kelompok neoliberal menolaknya karena menyiratkan klaim atas sumber daya (Lister, 2003). Kelompok neoliberal mengatakan bahwa hak sosial tidak bisa disamakan dengan hak sipil dan hak politik. Namun penolakan neoliberal ini mendapatkan sejumlah sanggahan. Salah satunya adalah argumen bahwa hak sosial ini justru membantu 
mempromosikan penggunaan hak sipil dan politik yang efektif dari kelompok yang tidak diuntungkan secara kekuasaan maupun sumber daya.Peran yang diberikan hak sosial adalah pada pengakuan bahwa otonomi tidak dapat dipahami hanya soal individualistik murni, tapi juga memiliki dimensi sosial (Lister, 2003).

Beberapa kelompok feminis melihat pentingnya hak sosial dalam memperlemah kekuasaan patriarkal dan memperkuat posisi perempuan dalam kewarganegaraan politik. Namun kelompok feminis radikal tetap melihat pendekatan hak sebagai ekspresi dari nilai dan kekuasaan laki-laki. Skeptisme mereka ini sama dengan kelompok radikal yang menyoroti "gagalnya kewarganegaraan dalam lembaga demokrasi liberal untuk memenuhi kebutuhan perempuan dan kelompok rasial serta kelompok yang termarginalisasi secara sosial dan ekonomi” (Lister, 2003).Yang menarik, dalam pendekatan hak, juga usulan atas hak reproduksi. Menurut David Held, hak reproduksi adalah kemungkinan yang sangat mendasar dari partisipasi perempuan secara efektif dalam masyarakat sipil dan politik. Ia mengidentifikasikan tujuh gugus hak yang sesuai dengan kekuasaan, yakni kesehatan, sosial, budaya, sipil, ekonomi, pasifis, dan hak politik.

Menurut Lister, perbedaan pandangan politik merupakan upaya untuk menggunakan prosedur politik universalisme sebagai jalan untuk mengakomodasi perbedaan nilai dalam prosedur demokrasi. Agar proses ini dapat berjalan, maka ada dua syarat penting, yaitu penerapan sistem politik yang inklusif terhadap perbedaan nilai dan orientasi politik, serta gerakan emansipatoris dari perempuan agar dapat merepresentasikan diri sebagai gerakan politik (Lister, 1997). Lister melihat melalui dua hal ini terjadi proses renegoisasi antara dua ranah berbeda, sehingga tercipta analisis seimbang dan komprehensif, dengan merekonstruksi kembali pembedaan ruang tersebut. Menurut Lister, dikotomi ruang privat dan ruang publik ini bukanlah sesuatu yang rigid, melainkan suatu proses yang dinamik untuk mempertemukan kepentingan partikularisme baik dari laki-laki maupun perempuan agar menjadi kepentingan universalisme karena keterhubungan diantara.

Munculnya komunitarianisme yang sering disebut sebagai kebangkitan republik sipil merupakan reaksi melawan individualisme dari paradigma kewarganegaraan liberal yang telah mendominasi kehidupan politik kontemporer. Beberapa kelompok feminis tertarik dengan gambaran republik sipil tentang kewarganegaraan sebagai partisipasi politik aktif dan keterlibatan dalam pengambilan keputusan, serta potensi kolektif dalam ranah publik untuk mengartikulasikan kepentingan perempuan dan “kelompok minoritas” (Lister, 2003).

Feminisme adalah sebuah paham yang muncul ketika wanita menuntut untuk mendapatkan kesetaraan Hak yang sama dengan pria. Pengakuan tentang ketidak seimbangan 
gender, dengan peran wanita yang berada di bawah pria. Pada awal abad ke 18 dapat dikatakan sebagai awal dalam sejarah feminisme, walaupun sudah ada wanita yang melakukan debat untuk mendapatkan posisi yang di akui dalam masyarakat, feminisme belum terlalu banyak berkembang pada saat itu. Pada saat itu yang bermunculan adalah para wanita yang menulis karya yang menunjukan tuntutan mereka untuk mendapatkan persamaan hak, khususnya di dalam bidang pendidikan.

perbedaan-perbedaan gender yaitu pada peran-peran yang berbeda yang dimainkan lakilaki dan perempuan dalam berbagai institusional. Peran-peran perempuan di institusi keluarga misalnya sebagai seorang ibu bagi anak dan istri bagi suaminya. Motif utama dari perspektif ini adalah pembagian kerja dilihat dari gender (laki-laki dan perempuan) di dalam institusi keluarga.

Menjadi sebuah dilematis ketika dalam pemilihan karir antara menyesuaikan passion(kerja) dengan menjadi Ibu Rumah Tangga atau pula keduanya (berkarir dan menjadi ibu Rumah Tangga). Seharusnya perempuan dan lak-laki tidak ada beda dalam perlakuan.

Model republik klasik menganjurkan bahwa semua warga negara harus terlibat secara langsung dalam pemerintahan masyarakat. Sementara kebanyakan perempuan mempraktikkan politik dalam tingkat lokal. Lister (2003) melihat bahwa perempuan tetap bisa memainkan peran penting dalam ruang publik meski mereka hanya menonjol di tingkat lokal karena ruang publik bukan hanya politik formal. Ruang publik juga meliputi, apa yang disebut Jean Lecca, sebagai “waduk kewarganegaraan”: gabungan dari berbagai asosiasi sukarelawan dari masyarakat sipil

Jaringan masyarakat sipil ini bisa berkontribusi secara tidak langsung dalam pengambilan keputusan negara. Untuk kebanyakan perempuan, keterlibatan dalam organisasi komunitas atau gerakan sosial ini kerap kali lebih efektif dibanding bergabung dalam politik formal. Gould mengatakan, "jika setiap manusia dihargai sebagai agen dengan kapasitas kebebasan memilih dan pengembangan diri”, tidak akan ada pijakan bagi satu jenis kelamin untuk memiliki hak lebih besar dengan menggunakan kapasitasnya dibanding yang lain dan mendominasi satu kelompok melalui penyangkalan terhadap kondisi agen yang setara. Kebebasan penuh perempuan oleh karenanya terletak pada kemampuan mereka berpartisipasi dalam mengendalikan kondisi ekonomi dan sosial hidup mereka, dan juga bebas dari diskriminasi dan dominasi (Lister, 2003).

\section{Simpulan}


Persoalan ketidaksetaraan dan ketidakadilan gender bukanlah persoalan sederhana dan berdimensi lokal, namun persoalan ini ditemui di seluruh belahan dunia, serta berkaitan erat dengan segala sendi kehidupan manusia. Maka tidaklah mengherankan jika boleh dikatakan perjuangan para pemerhati masalah perempuan, untuk meningkatkan kesetaraan dan keadilan gender yang sudah sekian lama seolah-olah jalan di tempat, atau paling sedikit hasil yang dicapai belum sesuai dengan harapan. 


\section{Daftar Pustaka}

AlRafni, Kesetaraan Gender Dalam Politik, Jurnal Kajian Ilmiah Gender, 3 (2), 145-171, 2013.

Arjani, N. L., Kesetaraan dan Keadilan Gender (KKG) dan Tantangan Global, Jurnal Ekonomi dan Sosial, 1 (2), 113-117, 2008.

Byrne, David, Social Exclusion. Second Edition. New York: Open University Press, 2005.

Ch, Mufidah, 2006, Rekonstruksi Kesetaraan dan Keadilan Gender Dalam Konteks Sosial Budaya dan Agama, Jurnal EGALITA, 1 (1), 1-22.

Kivisto. P \& Faist. T., 2007, Citizenship Discourse, Theory and Transnational Prospects, UK: Blackwell Publishing.

Lister, Ruth, 2003, Citizenship: Feminist Perspectives, Second Edition. New York: Palgrave Macmilan.

Mufidah, C. H., 2006, Rekonstruksi Kesetaraan dan Keadilan Gender Dalam Konteks Sosial Budaya dan Agama, Pusat Studi Gender UIN Maulana Malik Ibrahim Malang, 1 (1), 1 22.

Prasetio, dkk, 2014, Kesetaraan dan Keadilan Gender Dalam Jabatan Struktural Tahun 2013, Jurnal Ilmu Politik dan Pemerintahan, 3 (1), 86-90.

Pujiastuti, 2012, Peluang PNS Perempuan Dalam Memperoleh Jabatan Struktural: Studi Kualitas Kesetaraan Gender Di Pemerintahan Kota Semarang, Jurnal POLITIKA, 3 (2), 68-83.

Puspitawati, Herien, 2010, Persepsi Peran Gender Terhadap Pekerjaan Domestik dan Publik Pada Mahasiswa IPB, Jurnal Studi Gender \& Anak, 5 (1), 17-34.

Suryani, E., 2010, Sosialisasi Kesetaraan Gender Pada Pegawai Kantor Kesejahteraan Sosial dan Pemberdayaan Masyarakat Kabupaten Bekasi, Jurnal FISIP Kybernan, 1 (2), 1-20.

Thohari, A. A., 2012, Indonesia (The Aspects Of Constitutionality Of The Gender Equality In Indonesian Human Right Law, Jurnal Legislasi Indonesia, 9 (1), 1-13.

Zakia, Rahima, 2011, Kesetaraan dan Keadilan Gender Dalam Adat Minangkabau, Jurnal Ilmiah Kajian Gender, 1 (1), 39-52.

Undang-undang Dasar Negara Republik Indonesia Tahun 1945.

Undang-undang Nomor 12 Tahun 2006 Tentang Kewarganegaraan Republik Indonesia. 